\title{
Employees' Financial Literacy, Behavior, Stress and Wellness
}

\section{Robert Oton Parcia, Emeliza Torrento Estimo}

Administrative Department, Research Department, John B. Lacson Colleges Foundation, Bacolod City, Philippines

Email address:

robert.parcia@jblfmu.edu.ph (R. O. Parcia),emeliza.estimo@jblfmu.edu.ph (E. T. Estimo)

\section{To cite this article:}

Robert Oton Parcia, Emeliza Torrento Estimo. Employees' Financial Literacy, Behavior, Stress and Wellness. Journal of Human Resource Management. Vol. 5, No. 5, 2017, pp. 78-89. doi: 10.11648/j.jhrm.20170505.12

Received: October 14, 2017; Accepted: October 30, 2017; Published: December 12, 2017

\begin{abstract}
A successful financial wellness initiative may provide people with the information and support they need to achieve an ideal state of being, the balance of which is unique to every person. This correlational study aimed to examine the financial wellness of the employees of a maritime school and the factors that influence it. A survey was administered to 96 employees of the institution. Findings revealed that the employees have a fair level of financial wellness, a moderate level of financial literacy, a very satisfactory level of financial behavior, and a low level of financial stress. The employees were found to be comparably the same in their state of financial wellness regardless of their age, family status, sex, tenure, and job position. Overall, the data implied that what the employees earn was just enough to support their basic needs but not enough to cover for cases of sickness, job loss, or any form of emergency. The employees were comparably the same in terms of their financial literacy, all variables considered. They also demonstrate a comparable financial behavior, except when they were grouped according to age. Results of this study also indicate financial behavior being related to financial literacy. This result implies that being financially literate could improve the employees' ability to manage their financial resources. Financial literacy was found to be the best predictor of financial wellness.
\end{abstract}

Keywords: Employees' Financial Wellness, Financial Literacy, Financial Stress, Financial Behavior, Descriptive Design

\section{Introduction}

Financial wellness, also referred to as financial health, is a crucial issue which confronts people in all walks of life. With the prices of commodities soaring up and the cost of living being higher than what most of the Filipino families are earning, daily survival has become a challenge even for working professionals. In the United States, the PwC's Employee Financial Wellness Survey conducted in 2015 which tracks the financial wellbeing of full-time employed U. S. adults nationwide reported that $20 \%$ of employees who earn $\$ 100,000$ or more find it difficult to meet household expenses on time each month [1].

Certain practices can adversely affect a person's financial wellness, causing him financial troubles. Some of these practices include inability to properly manage debt, overspending, not having an emergency fund, inadequate shopping and spending skills, low salary and lack of knowledge about money [2]. These practices can lead to financial stress in that employees who have difficulty paying everyday expenses and recurring bills, have reduced options for improving their financial condition, or who feel that their financial condition limits their choices can feel stress and that stress carries over to work. Signs of financial stress could include higher rates of absenteeism, loans from retirement plans, wage garnishments, and pay-day advances [3]. Therefore, financial problems and financial stress affect not only an individual's personal and family life but also his work life.

One of the causes of financial problems is the lack of financial knowledge or the lack of understanding of how to manage, save, and invest money. Low level of financial literacy has been linked with abuse of credit and living beyond one's financial means [4]. In the Philippines, it was reported that only 25 percent of Filipino adults are financially literate [5]. According to the same source, only one in three adults or 31 percent shows an understanding of basic financial concepts.

It is important that an individual must be financially literate. This literacy will enhance his ability to handle day to day financial matters and will reduce the negative consequences of poor financial decisions that otherwise 
might take years to overcome. Many people lack the financial literacy needed to make important financial decisions for their best interests [6], [7]. Moreover, experts generally agree that financial knowledge appears to be directly correlated with financial behavior [8]. Poor financial behaviors and personal and family money management practices have consequential, detrimental and negative impacts on one's life at home and work [9].

A survey of 329 human resources and employee benefits managers found a growing interest among employers in offering financial education to their employees [10]. However, less than half of companies surveyed offered programs to help employees with their financial problems. Employees are also reaching out to their employers for direction and support when it comes to their financial problems.

Every institution must include among its objectives initiatives to promote and protect the welfare and wellness of all the employees, financial wellness included. However, it can only offer a sound financial direction if given a baseline data of the financial condition of its employees. The school needs to obtain a clear picture of the employees' state of financial wellness. This idea is supported by Delafrooz and Paim [11] who claim that an objective assessment of a person's financial situation is necessary for the investigation of an individual's financial wellness. It is also equally significant to investigate the factors that influence it; hence, this study.

\subsection{Framework}

Some existing theories were found useful in establishing the grounds for this study. The assumptions held by these theories and their applications in this study are discussed below.

\subsubsection{Maslow's Hierarchy of Needs Theory}

Maslow's (1943) Hierarchy of Needs proposed that motivation is the result of a person's attempt at fulfilling his five basic needs. These needs, according to him, can create internal pressures that can influence a person's behavior. His Hierarchy of Needs includes physiological needs, safety needs, social needs, self-esteem, and self-actualization. Maslow believed that these needs exist in a hierarchical order. This progression principle suggests that lower-level needs must be met before higher-level needs. The deficit principle claims that once a need is satisfied, it is no longer a motivator because an individual will take action only to satisfy unmet needs. In this study, the need to be satisfied with their physiological and safety needs are essential for the employees. Being able to provide for their personal and family needs, which could depend highly not only on the salary that they receive but also on how they manage this, could affect their attainment of the rest of their needs in the hierarchy. It is considered an extended responsibility of the employers to help ensure that these needs are addressed to provide the employees a sense of security and well-being. Hence, beyond their duty to pay their salaries on time, employers can educate their workers on how to manage their financial resources to offer them a more secure and contented life.

\subsubsection{Life-Cycle Theory}

The Life-cycle theory makes its first appearance in two papers that Modigliani wrote in the early 1950s with a graduate student, Richard Brumberg (Modigliani and Brumberg 1954 and 1980). According to this theory, an individual's or household's level of consumption depends not just on current income but also, and more importantly, on long-term expected earnings. People are assumed to plan a pattern of consumer expenditure based on expected earnings over their lifetime [12].

In the life cycle hypothesis, consumption and saving behavior are dependent on the individual's position in the life cycle. Young workers entering the labor force have relatively low incomes and low (possibly negative) saving rates. As income rises in middle-age years so does the saving rate. Retirement brings a fall in income and might be expected to begin a period of dissaving (negative saving rates). This pattern of consumption and income results in periods of dissaving during the early working years and the late stage of the life cycle, and positive-saving over the high-incomemiddle-period of the life cycle. The challenge then is how an individual can be able to manage the decline of his income in his retirement years amidst the steadily increasing cost of expenditures. This implies the need to carefully plan and manage his financial resources while it is at its peak.

Given the assumptions held by the Life-Cycle Theory, this study aims to examine the financial literacy of employees, their financial behavior and the level of stress that they face in relation to how they manage their income. The results will be utilized in designing a financial program that could assist the employees in improving their spending lifestyle while at the prime of their life in preparation for their years of retirement.

\subsubsection{Joo's (1998) Conceptual Model of Personal Financial Wellness and Worker Job Productivity}

This model holds that the demographic characteristics of an individual such as his marital status, income, education, age and the number of dependents in the household, as well as his financial knowledge and his financial behavior influence his financial wellness [13]. Financial literacy comes with the individual's knowledge of how to manage his financial resources for his life's satisfaction. Financial behavior, on the other hand, refers to positive and desirable behaviors that are recommended as a best practice of financial activities [14]. An example of this is maintaining reasonable and low debt, intentionally following a personal spending plan, having an active savings plan, and the lack of money-related conflict with family or partner. A person's financial behavior is affected by his financial literacy [15], [8]. Moreover, financial stressors such as life cycle events, job-related events, unexpected changes, and unfavorable financial situations affect a person's financial wellness. Financial stress can be adversely caused by an individual's 
lack of financial knowledge, undesirable financial behavior, and certain demographic variables. It is also negatively related to financial satisfaction. In a study among health care professionals, it was revealed that financial stress explained $30 \%$ of the variance in participant financial wellness scores. Financially stressed workers are also less satisfied with their jobs and their pay, and are more likely to go looking for greener pastures elsewhere. They are also more tempted to steal from their employer [16]. Furthermore, it was earlier established that demographic characteristics and financial literacy can have impacts on financial behaviors. Individuals who have low incomes, less education and less financial knowledge are more likely to make different financial decisions than others, resulting in varying behaviors and financial outcomes.

Given these theoretical underpinnings, the proposed conceptual framework of this study incorporates the interrelated influence of demographic characteristics, financial literacy, financial behavior, and financial stress levels on an individual's financial wellness. These concepts are illustrated in the following diagram:

\begin{tabular}{|l|}
\hline \multicolumn{2}{|l|}{ Demographic } \\
Characteristics \\
- Age \\
- Family \\
- Status \\
- Sex \\
- Monthly \\
- Income \\
- Job Position \\
\hline
\end{tabular}

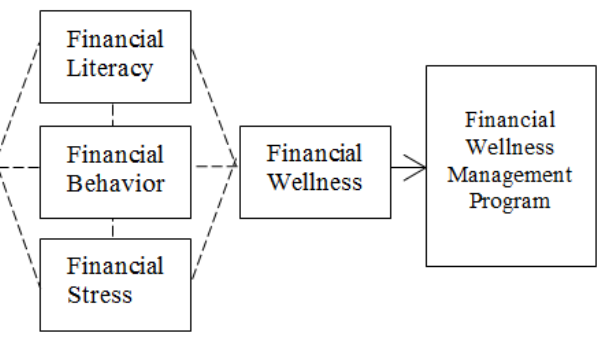

Figure 1. Paradigm of the Study.

\subsection{Research Problems}

This study aimed to examine the financial wellness of the employees of a maritime school in the Philippines, to determine their financial literacy, financial behavior, and financial stress, and to find out which of these factors could determine their financial wellness. The following questions were addressed in this study:

1. What is the employees' level of financial wellness, financial literacy, financial behavior, and financial stress when they are taken as a whole and when grouped according to the following variables?

a. Age

b. Family Status

c. Sex

d. Monthly Income

e. Job Position

f. Tenure

2. Is there a significant difference in the level of financial wellness, financial literacy, financial behavior, and financial stress of the employees when they are grouped according to the same variables?

3. Is there a significant relationship between the employees' financial literacy and financial behavior, financial literacy and financial stress, and financial behavior and financial stress?

4. Which among these factors could determine the employees' financial wellness?

\subsection{Hypotheses}

The following hypotheses were raised in the study:

1. There is no significant difference in the level of financial wellness, financial literacy, financial behavior, and financial stress of the employees when they are grouped according to age, family status, sex, monthly income, job position, and tenure.

2. There is no significant relationship between the employees' financial literacy and financial behavior, financial literacy and financial stress, and financial behavior and financial stress.

3. Financial literacy, financial behavior, and financial stress cannot determine the financial wellness of the employees.

\section{Methods}

\subsection{Research Design}

This investigation employed a descriptive-correlational design. This design explores the relationship between two or more quantifiable variables to figure out which variables are connected or are closely interacting with each other so that when you can see one change, you have an idea of how the other will change [17]. Correlation can be positive or negative. A positive correlation means that as Variable A increases, Variable B also increases. A negative correlation happens when as Variable A increases, variable B decreases. Quantitative data in this study were derived from a set of surveys that were administered to the employees of the school.

\subsection{Respondents}

The respondents for this study covered 96 employees of the institution. These respondents were further grouped according to age, marital status, sex, and income.

\subsection{Research Instrument}

A researcher-made survey questionnaire was used in this study. The survey instrument was composed of five parts. Part 1 was designed to obtain the demographic characteristics of the respondents as needed in this study. Part 2, 3, 4 and 5 were designed to determine the employees' level of financial wellness, financial literacy, financial behavior, and financial stress respectively. The respondents were asked to rate each of these parts using a five-point Likert scale. The survey questionnaire was content validated by a jury experts composed of a Certified Public Accountant and two others being Ph. D. degree holders. Using the criteria of Good and Scates, the instrument obtained a score of 4.78 , interpreted as excellent. A reliability score of .88 , interpreted as good, was obtained using Cronbach's alpha. 


\subsection{Statistical Tools}

To determine the employees' level of financial wellness, financial literacy, financial behavior, and financial stress when they are taken as a whole and when grouped according to age, family status, sex and monthly income, the mean and standard deviation were used. The following scales were used in interpreting the data:

Table 1. Scale for the interpretation the mean.

\begin{tabular}{llll}
\hline \multicolumn{2}{l}{\begin{tabular}{l} 
Financial Literacy and \\
\multicolumn{2}{l}{ Financial Stress }
\end{tabular}} & $\begin{array}{l}\text { Financial Wellness and Financial } \\
\text { Behavior }\end{array}$ \\
\hline $4.20-5.00$ & Very High & $4.20-5.00$ & Excellent \\
$3.40-4.19$ & High & $3.40-4.19$ & Very Satisfactory \\
$2.60-3.39$ & Moderate & $2.60-3.39$ & Fair \\
$1.80-2.59$ & Low & $1.80-2.59$ & Poor \\
$1.00-1.79$ & Very Low & $1.00-1.79$ & Very Poor \\
\hline
\end{tabular}

To find out if a significant difference exists in the level of financial wellness, financial literacy, financial behavior, and financial stress of the employees when they are grouped according to the same variables, t-Test and Analysis of Variance were employed. Furthermore, to find out if a significant relationship exists between the employees' financial literacy and financial behavior, financial literacy, and financial stress, and financial behavior and financial stress, Pearson's $r$ was used.

\section{Results}

This section of the paper reports and discusses the results of this study based on the questions that were earlier raised in this paper.

\subsection{Employees' Level of Financial Wellness, Financial Literacy, Financial Behavior, and Financial Stress When Taken as a Whole}

The first concern of this study was to find out the employees' level of financial wellness, financial literacy, financial behavior, and financial stress when taken as a whole.

\subsubsection{Financial Wellness}

Financial wellness or financial health (also referred to as 'financial well-being') is a state where an individual enjoys satisfaction with income and savings, awareness of opportunities, ability to make ends meet, sense of material security, and sense of fairness of the reward distribution system [13].

In Table 2, it can be seen that the employees have a fair level of financial wellness as a whole. In particular, they assign the highest rating for the statement $I$ ' can provide for my family and other personal basic needs"with a mean of 3.44 , interpreted as very satisfactory, and the lowest rating for "I have set aside emergency or rainy day funds that would cover my expenses for at least three months in case of sickness, job loss, economic downturn, or other emergencies" with a mean of 2.91, interpreted as fair. It can also be noted that there is a higher dispersion of the values as indicated by the standard deviation of 1.34 for the item "I have other sources of funds aside from my salary." This indicates a higher variability in terms of the respondents' responses to this particular item which means that some employees have scored themselves very high while others have scored themselves very low. This high dispersion from the mean score could mean that some employees have other alternative sources of income aside from their salary while others may not have. This explains the fact that whenever there is a little delay in the posting of salary online, a lot of the employees can be heard complaining about where to get their budget intended for the family needs for that particular payday. Overall, the data imply that what the employees earn is just enough to support their basic needs, but there is hardly more than enough to cover for cases of sickness, job loss or any form of emergencies. Data also imply that a number of them do not have other sources of funds except their salary.

Table 2. Employees' level of financial wellness when taken as a whole.

\begin{tabular}{|c|c|c|c|c|}
\hline Indicators & Mean & SD & Interpretation & Rank \\
\hline I am satisfied with my current personal financial condition. & 3.30 & 0.98 & Fair & 3 \\
\hline I am confident towards my retirement savings. & 3.19 & 1.13 & Fair & 6 \\
\hline What I am earning is enough to sustain me until the next payday. & 3.27 & 1.05 & Fair & 4 \\
\hline I can cope with all my regular monthly bills (children's education, utilities, etc.) & 3.22 & 1.11 & Fair & 5 \\
\hline $\begin{array}{l}\text { I have set aside emergency or rainy day funds that would cover my expenses for at least three } \\
\text { months in case of sickness, job loss, economic downturn, or other emergencies. }\end{array}$ & 2.91 & 1.19 & Fair & 10 \\
\hline I have other sources of funds aside from my salary. & 2.94 & 1.34 & Fair & 8 \\
\hline I can regularly pay my credit card bills, mortgage, and other loan obligations. & 3.37 & 1.07 & Fair & 2 \\
\hline I am earning more than what I spend. & 2.92 & 1.20 & Fair & 9 \\
\hline I can acquire/purchase what I decide to. & 2.98 & 1.16 & Fair & 7 \\
\hline Total & 3.13 & 0.87 & Fair & \\
\hline
\end{tabular}

\subsubsection{Financial Literacy}

Financial literacy was defined as the ability to make informed judgments and to take effective decisions regarding the use and management of money [18]. Table 3 reveals the employees have a moderate level of financial literacy. Data show that they assign the highest value on their knowledge to keep track of their money with a mean of 3.56, interpreted as high, followed by their knowledge of the importance of saving and how much should be set aside as emergency 
savings and basic budgeting.

In contrast, they assign the lowest value to their knowledge of shopping around to get the best financial product such as loans or insurance rates; knowledge of different investments like time deposits, money market, and stock market; and staying informed about financial issues. These results imply the need to enhance the financial literacy of the employees. If their financial literacy is just set at moderate level, they could also fall short of their ability to practice more positive financial activities [14], hence, could experience a higher level of financial stress due to mismanagement of financial resources.

Table 3. Employees' level of financial literacy when taken as a whole.

\begin{tabular}{|c|c|c|c|c|}
\hline Indicators & Mean & SD & Interpretation & Rank \\
\hline Keeping track of your money & 3.56 & 0.94 & High & 1 \\
\hline Making ends meet & 3.35 & 0.96 & Moderate & 4 \\
\hline Shopping around to get the best financial product such as loans or insurance rates & 2.93 & 1.13 & Moderate & 10 \\
\hline Staying informed about financial issues. & 3.07 & 0.91 & Moderate & 8 \\
\hline The benefits and protection of various forms of insurance & 3.13 & 1.06 & Moderate & 7 \\
\hline The importance of saving and how much should be set aside as emergency savings & 3.55 & 0.98 & High & 2 \\
\hline Reading and interpreting financial statements & 3.24 & 0.90 & Moderate & 5 \\
\hline Knowledge of different investments like time deposits, money market, and stock market & 3.01 & 1.04 & Moderate & 9 \\
\hline Understanding what is meant by interest rate and cost of money & 3.23 & 1.14 & Moderate & 6 \\
\hline Total & 3.23 & 0.78 & Moderate & \\
\hline
\end{tabular}

\subsubsection{Financial Behavior}

Financial behavior refers to positive and desirable behaviors that are recommended as a best practice of financial activities [14]. An example of this is maintaining reasonable and low debt, intentionally following a personal spending plan, having an active savings plan, and the lack of money-related conflict with family or partner.

Data shown in Table 4 reveal that the employees have a very satisfactory level of financial behavior. The employees rated themselves highest on the following items: I pay in cash to purchase food and other basic needs instead of using a credit card, I consider my financial situation before deciding to purchase anything, and I pay my bills/loans on time. In contrast, they scored themselves lowest on I own a bank account which I update every month, I make comparisons before asking for loans or using credit cards, and I carefully check the details of my bank statements/credit card bills. These results imply that the employees are wise spenders and good payers as a whole. This could be because the salary that they earn is just enough to support their basic needs. It could be that they had gotten used to carefully planning their budget to fit their needs; hence, they have grown more conscious and selective about what they spend for. However, they seem to be less cautious when it comes to using their credit cards. They also scored themselves lowest in terms of owning a bank account, a result which implies that a number of them might not have anything left of their salary to start a bank account for their savings.

Table 4. Employees' level of financial behavior when taken as a whole.

\begin{tabular}{|c|c|c|c|c|}
\hline Indicators & Mean & SD & Interpretation & Rank \\
\hline I pay my bills/loans on time. & 3.78 & 0.95 & Very Satisfactory & 3 \\
\hline I own a bank account which I update every month. & 2.99 & 1.47 & Fair & 10 \\
\hline I pay in cash to purchase food and other basic needs instead of using a credit card. & 3.83 & 1.11 & Very Satisfactory & 1 \\
\hline I carefully check the details of my bank statements/credit card bills. & 3.30 & 1.29 & Fair & 8 \\
\hline I make comparisons before asking for loans or using credit cards. & 3.22 & 1.29 & Fair & 9 \\
\hline I discuss with spouse on financial issue/ I ask sound advice on financial matters from others. & 3.46 & 1.33 & Very Satisfactory & 6 \\
\hline I consider my financial situation before deciding to purchase anything. & 3.79 & 1.04 & Very Satisfactory & 2 \\
\hline I am very particular with how much I can save by carefully selecting items to purchase. & 3.71 & 1.10 & Very Satisfactory & 4 \\
\hline Total & 3.48 & 0.92 & Very Satisfactory & \\
\hline
\end{tabular}

This result explains why they also scored themselves low on the item "I have set aside emergency or rainy day funds that would cover my expenses for at least three months in case of sickness, job loss, economic downturn, or other emergencies."

\subsubsection{Financial Stress}

Financial stress is a form of stress that comes from being in debt, being unable to make the rent/mortgage repayment or knowing you're going to have to spend a huge amount of money [19]. In this study, it refers to a condition where an individual is bothered or disturbed by any problem which affects his or her financial wellness due to mismanagement of his or her financial resources.

Table 5 reveals that the employees have a low level of financial stress. However, when the data are examined carefully, it can be seen that on top of their worries is the item "I am wondering how I can afford the medical cost in 
case of sickness or ailment" followed by "I find it hard to provide all the needs of my family" and "My net pay is always not enough to cover my family's needs until the next payday." In contrast, the least among their concerns are the items "I have an unsettled problem with a collection agency," Too much worry over my financial state affects my focus at work," and "I often experience high blood pressure thinking about how to make ends meet in terms of our family budget.
The data imply that even when there are financial concerns that worry them, they try not to allow these problems to seriously affect them or the quality of their work. This attitude is reflective of a high level of resilience among the employees who can find ways to make ends meet. This implies that as long as they are in good health and there will be no untoward emergencies that might befall them, they are still able to survive from their financial worries.

Table 5. Employees' level of financial stress when taken as a whole.

\begin{tabular}{|c|c|c|c|c|}
\hline Indicators & Mean & SD & Interpretation & Rank \\
\hline I have trouble paying my bills on time. & 2.38 & 1.13 & Low & 6 \\
\hline I am wondering how I can afford the medical cost in case of sickness or ailment. & 2.98 & 1.09 & Moderate & 1 \\
\hline I find it hard to provide all the needs of my family. & 2.69 & 1.07 & Moderate & 2 \\
\hline I am in daze every time my children/dependent (s) inform me about their upcoming exams. & 2.47 & 1.11 & Low & 5 \\
\hline I am unable to save for my future needs. & 2.58 & 1.21 & Low & 4 \\
\hline I have an unsettled problem with a collection agency. & 1.82 & 1.06 & Low & 10 \\
\hline I have trouble sleeping thinking about my financial condition. & 2.12 & 1.18 & Low & 7 \\
\hline Too much worry over my financial state affects my focus at work. & 2.04 & 1.12 & Low & 9 \\
\hline My net pay is always not enough to cover my family's needs until the next payday. & 2.67 & 1.22 & Moderate & 3 \\
\hline Total & 2.42 & 0.88 & Low & \\
\hline
\end{tabular}

\subsection{Level of Financial Wellness, Literacy, Behavior, and Stress When Viewed According to Age, Family Status, Sex, Monthly Income, Job Position, and Tenure}

The following portions report and discuss the level of financial wellness, financial literacy, financial behavior, and financial stress of the employees when grouped according to age, family status, sex, monthly income, job position, and tenure. Slight differences can be noted by comparing the means obtained by each group.

\subsubsection{Financial Wellness}

Table 6 shows that employees who belong to the youngest group have rated themselves highest while the most senior group rated themselves lowest in terms of financial wellness. Employees without dependents scored themselves higher than those with dependents. Male employees reported a higher mean than their female counterparts.

Table 6. Employees' level of financial wellness.

\begin{tabular}{|c|c|c|c|c|}
\hline Variables & Group & Mean & SD & Interpretation \\
\hline \multirow{3}{*}{ Age } & $20-33$ & 3.17 & 0.74 & Fair \\
\hline & $34-47$ & 3.14 & 0.99 & Fair \\
\hline & $48 \&$ Above & 3.12 & 0.83 & Fair \\
\hline \multirow{2}{*}{ Family Status } & With Dependents & 3.11 & 0.75 & Fair \\
\hline & Without Dependents & 3.20 & 0.78 & Fair \\
\hline \multirow{2}{*}{ Sex } & Male & 3.15 & 0.88 & Fair \\
\hline & Female & 3.10 & 0.84 & Fair \\
\hline \multirow[t]{2}{*}{ Monthly Gross Income } & P25,000-P49,000 & 3.16 & 0.85 & Fair \\
\hline & P24,000 \& Below & 3.01 & 0.79 & Fair \\
\hline \multirow{5}{*}{ Tenure } & 1-5 Years & 3.06 & 0.72 & Fair \\
\hline & 6-10 Years & 2.75 & 0.63 & Fair \\
\hline & 11-20Years & 3.30 & 0.73 & Fair \\
\hline & 21-30Years & 3.62 & 1.06 & Very Satisfactory \\
\hline & 31 Years \& above & 2.73 & 0.37 & Fair \\
\hline Job Position & Non-Teaching Staff & 3.10 & 0.85 & Fair \\
\hline Total & & 3.13 & 0.87 & Fair \\
\hline
\end{tabular}

Those receiving the highest scale of monthly income and who have stayed with the school for 21 to 30 years reported a very satisfactory level of financial wellness. It is worth mentioning that these are the same employees who are occupying management level positions in the school and are receiving the highest salary scale. Those who are teaching rated themselves higher on financial wellness as compared to the non-teaching staff. Overall, the employees rated their financial wellness as fair.

\subsubsection{Financial Literacy}

In terms of financial literacy, Table 7 reveals that employees between 34 to 47 years old appear to be more financially literate than those who belong to the younger or older groups. It is the male employees who appear to be more financially literate than female employees. Employees with dependents claim to be more financially literate than those without dependents. In terms of monthly, income, the highest 
earning group has high financial literacy compared to the rest whose literacy is only moderate. This implies that the higher they earn; the more conscious they are when it comes to knowing how to manage their financial resources. Employees who have stayed at the school for 21 to 30 years rated themselves highest when it comes to financial literacy.

When it comes to position, the difference is almost marginal between teaching and non-teaching employees. As a whole, the financial literacy of employees is rated as moderate, a level which only falls as average.

Table 7. Employees' level of financial literacy.

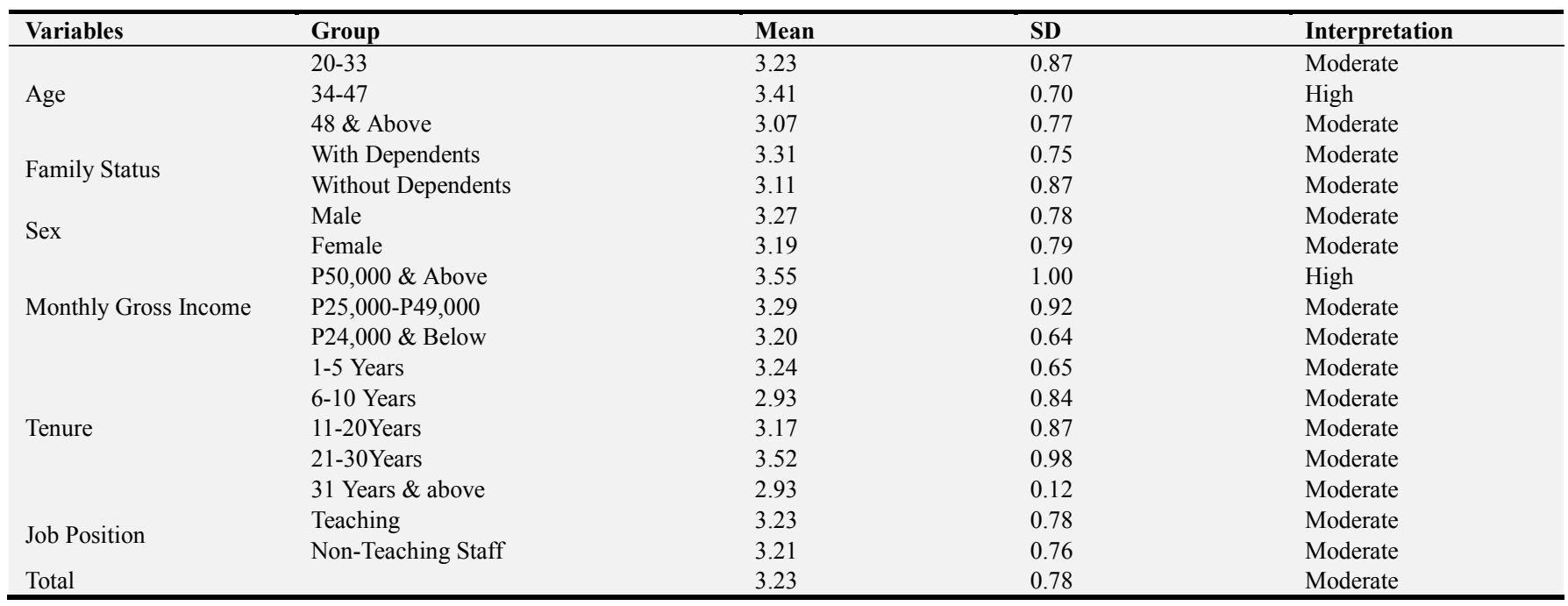

\subsubsection{Financial Behavior}

In terms of financial behavior, Table 8 reports that employees between 34 to 47 years rated themselves higher than those who belong to the younger or older groups. This is the same age group that appeared to have the highest level of literacy.

Employees with dependents appear to have a better financial behavior compared to those without dependents.

Female employees show a better financial behavior compared to their male counterparts. This is interesting because it is the male employees who rated themselves higher in terms of financial literacy. It is those who are in the highest salary scale and those who have served the school for 21 to 30 years who rated themselves highest in terms of financial behavior.

Finally, teaching employees show a better financial behavior compared to those who are not teaching. Overall, the financial behavior of the employees is described as very satisfactory.

Table 8. Employees' level of financial behavior.

\begin{tabular}{|c|c|c|c|c|}
\hline Variables & Group & Mean & SD & Interpretation \\
\hline \multirow{3}{*}{ Age } & $20-33$ & 3.49 & 0.92 & Very Satisfactory \\
\hline & $34-47$ & 3.76 & 0.86 & Very Satisfactory \\
\hline & $48 \&$ Above & 3.20 & 0.91 & Very Satisfactory \\
\hline \multirow{2}{*}{ Family Status } & With Dependents & 3.50 & 0.92 & Very Satisfactory \\
\hline & Without Dependents & 3.45 & 0.94 & Very Satisfactory \\
\hline \multirow{2}{*}{ Sex } & Male & 3.47 & 0.89 & Very Satisfactory \\
\hline & Female & 3.52 & 0.98 & Very Satisfactory \\
\hline \multirow[t]{2}{*}{ Monthly Gross Income } & $\mathrm{P} 25,000-\mathrm{P} 49,000$ & 3.62 & 0.99 & Very Satisfactory \\
\hline & P24,000 \& Below & 3.35 & 0.83 & Very Satisfactory \\
\hline \multirow{5}{*}{ Tenure } & 1-5 Years & 3.38 & 0.89 & Moderate \\
\hline & 6-10 Years & 3.30 & 0.92 & Moderate \\
\hline & 11-20 Years & 3.58 & 0.85 & Very Satisfactory \\
\hline & 21-30Y ears & 3.71 & 1.07 & Very Satisfactory \\
\hline & 31 Years \& above & 2.70 & 0.52 & Low \\
\hline Total & & 3.48 & 0.92 & Very Satisfactory \\
\hline
\end{tabular}

\subsubsection{Financial Stress}

Table 9 reveals that while the rest of the groups of employees have a low level of financial stress, those who belong to the age group of 34 to 47 years old, those who have served the school for 31 years or more, and those who belong to the teaching group show a moderate level of financial stress. It should be recalled that it is this age group (34 to 47 years old) that showed the highest level of financial literacy and financial behavior. 
Moreover, it should also be recalled that it is those who

have rated themselves lowest in terms of the same factors. have served the school the longest (31 years and above) who

Table 9. Employees' level of financial stress.

\begin{tabular}{|c|c|c|c|c|}
\hline Variables & Group & Mean & SD & Interpretation \\
\hline \multirow{3}{*}{ Age } & $20-33$ & 2.19 & 0.76 & Low \\
\hline & $34-47$ & 2.69 & 0.95 & Moderate \\
\hline & $48 \&$ Above & 2.31 & 0.83 & Low \\
\hline \multirow{2}{*}{ Family Status } & With Dependents & 2.44 & 0.84 & Low \\
\hline & Without Dependents & 2.37 & 0.97 & Low \\
\hline \multirow{2}{*}{ Sex } & Male & 2.56 & 0.93 & Low \\
\hline & Female & 2.18 & 0.74 & Low \\
\hline \multirow[t]{2}{*}{ Monthly Gross Income } & $\mathrm{P} 25,000-\mathrm{P} 49,000$ & 2.41 & 0.97 & Low \\
\hline & P24,000 \& Below & 2.55 & 0.78 & Low \\
\hline \multirow{5}{*}{ Tenure } & 1-5 Years & 2.50 & 0.77 & Low \\
\hline & 6-10 Years & 2.26 & 0.75 & Low \\
\hline & 11-20Years & 2.54 & 1.03 & Low \\
\hline & 21-30Years & 2.42 & 1.17 & Low \\
\hline & 31 Years \& above & 2.83 & 0.76 & Moderate \\
\hline Total & & 2.42 & 0.88 & Low \\
\hline
\end{tabular}

\subsection{Difference in the Employees' Level of Financial Wellness, Literacy, Behavior, and Stress When Grouped According to Variables}

Another concern of this study was to find out if there exists a significant difference in the employees' level of financial wellness, financial literacy, financial behavior, and financial stress when the same variables are considered. Table 10 reveals that there is no significant difference in the financial wellness of the employees when they are grouped according to age, family status, sex, tenure, and job position. When they are grouped according to monthly gross income, however, a significant difference in their financial wellness exists.

This result implies that among the variables considered in this study, it is the how much the employees earn that spells the difference in their financial wellness.

Table 10. Difference in the employees' level of financial wellness.

\begin{tabular}{|c|c|c|c|c|c|c|}
\hline Variables & Group & Mean & SD & F $(2,93)$ & p & Interpretation \\
\hline \multirow{4}{*}{ Age } & $20-33$ & 3.17 & 0.74 & \multirow{3}{*}{0.025} & \multirow{3}{*}{0.98} & \multirow{3}{*}{ Not Significant } \\
\hline & $34-47$ & 3.14 & 0.99 & & & \\
\hline & $48 \&$ Above & 3.12 & 0.83 & & & \\
\hline & & Mean & $\mathrm{SD}$ & $\mathrm{T}(94)$ & $\mathrm{p}$ & Interpretation \\
\hline \multirow{2}{*}{ Family Status } & With Dependents & 3.11 & 0.75 & \multirow{2}{*}{-0.48} & \multirow{2}{*}{0.30} & \multirow{2}{*}{ Not Significant } \\
\hline & Without Dependents & 3.20 & 0.78 & & & \\
\hline \multirow{3}{*}{ Sex } & & Mean & SD & $\mathrm{T}(94)$ & $\mathrm{p}$ & Interpretation \\
\hline & Female & 3.10 & 0.84 & 0.27 & 0.81 & Not Significant \\
\hline & & Mean & $\mathrm{SD}$ & $F(2,93)$ & $\mathrm{p}$ & Interpretation \\
\hline \multirow{4}{*}{ Monthly Gross Income } & P50,000 \& Above & 4.17 & 1.04 & \multirow{3}{*}{5.26} & \multirow{3}{*}{$0.01 *$} & \multirow{3}{*}{ Significant } \\
\hline & P25,000-P49,000 & 3.16 & 0.85 & & & \\
\hline & P24,000 \& Below & 3.01 & 0.79 & & & \\
\hline & & Mean & SD & $\mathrm{F}(4,91)$ & $\mathrm{p}$ & Interpretation \\
\hline \multirow{5}{*}{ Tenure } & 1-5 Years & 3.06 & 0.72 & \multirow{4}{*}{2.52} & \multirow{4}{*}{0.06} & \multirow{4}{*}{ Not Significant } \\
\hline & 6-10 Years & 2.75 & 0.63 & & & \\
\hline & 21-30Years & 3.62 & 1.06 & & & \\
\hline & 31 Years \& above & 2.73 & 0.37 & & & \\
\hline & & Mean & $\mathrm{SD}$ & $\mathrm{T}(94)$ & $\mathrm{p}$ & Interpretation \\
\hline \multirow{2}{*}{ Job Position } & Teaching & 3.15 & 0.90 & \multirow{2}{*}{0.27} & \multirow{2}{*}{0.63} & \multirow{2}{*}{ Not Significant } \\
\hline & Non-Teaching Staff & 3.10 & 0.85 & & & \\
\hline
\end{tabular}

Table 11 shows that there is no significant difference in the employees' level of financial literacy when grouped according to all the variables considered in this study. This means that regardless of their age, family status, sex, monthly income, job position, or tenure, they are comparably the same when it comes to their financial literacy. 
Table 11. Difference in the employees' level of financial literacy.

\begin{tabular}{|c|c|c|c|c|c|c|}
\hline Variables & Group & Mean & SD & $F(2,93)$ & $\mathbf{p}$ & Interpretation \\
\hline \multirow{4}{*}{ Age } & $20-33$ & 3.23 & 0.87 & & & \\
\hline & $34-47$ & 3.14 & 0.70 & 1.65 & 0.20 & Not Significant \\
\hline & $48 \&$ Above & 3.07 & 0.77 & & & \\
\hline & & Mean & SD & $\mathrm{T}(94)$ & $\mathrm{p}$ & Interpretation \\
\hline \multirow{3}{*}{ Family Status } & With Dependents & 3.31 & 0.75 & $11+4$ & 0.59 & Not Significant \\
\hline & Without Dependents & 3.11 & 0.87 & 1.174 & & 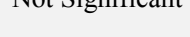 \\
\hline & & Mean & SD & $\mathrm{T}(94)$ & $\mathrm{p}$ & Interpretation \\
\hline \multirow{3}{*}{ Sex } & Male & 3.27 & 0.78 & 0.45 & 0.98 & Not Significant \\
\hline & Female & 3.19 & 0.79 & & & 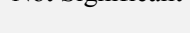 \\
\hline & & Mean & SD & $\mathrm{F}(2,93)$ & $\mathrm{p}$ & Interpretation \\
\hline \multirow{4}{*}{ Monthly Gross Income } & P50,000 \& Above & 3.55 & 1.00 & & & \\
\hline & $\mathrm{P} 25,000-\mathrm{P} 49,000$ & 3.29 & 0.92 & 0.63 & 0.54 & Not Significant \\
\hline & P24,000 \& Below & 3.20 & 0.64 & & & \\
\hline & & Mean & $\mathrm{SD}$ & $\mathrm{F}(4,91)$ & $\mathrm{p}$ & Interpretation \\
\hline \multirow{6}{*}{ Tenure } & 1-5 Years & 3.24 & 0.65 & & & \\
\hline & 6-10 Years & 2.93 & 0.84 & & & \\
\hline & 11-20Years & 3.17 & 0.87 & 1.18 & 0.33 & Not Significant \\
\hline & 21-30Years & 3.52 & 0.98 & & & \\
\hline & 31 Years \& above & 2.93 & 0.12 & & & \\
\hline & & Mean & SD & $\mathrm{T}(94)$ & $\mathrm{p}$ & Interpretation \\
\hline \multirow{2}{*}{ Job Position } & Teaching & 3.23 & 0.78 & 0.20 & 0.92 & Not Sionificant \\
\hline & Non-Teaching Staff & 3.21 & 0.76 & 0.20 & 0.92 & Not Signiticantit \\
\hline
\end{tabular}

A significant difference in the employees' level of financial behavior when grouped according to age was noted as shown in Table 12 .

Table 12. Difference in the employees' level of financial behavior.

\begin{tabular}{|c|c|c|c|c|c|c|}
\hline Variables & Group & Mean & Sd & F $(2,93)$ & $\mathbf{P}$ & Interpretation \\
\hline \multirow{4}{*}{ Age } & $20-33$ & 3.49 & 0.92 & \multirow{3}{*}{3.34} & \multirow{3}{*}{$0.04 *$} & \multirow{3}{*}{ Significant } \\
\hline & $34-47$ & 3.76 & 0.86 & & & \\
\hline & $48 \&$ Above & 3.20 & 0.91 & & & \\
\hline & & Mean & SD & $\mathrm{T}(94)$ & $\mathrm{P}$ & Interpretation \\
\hline \multirow{3}{*}{ Family Status } & With Dependents & 3.50 & 0.92 & \multirow{2}{*}{0.24} & \multirow{2}{*}{0.84} & \multirow{2}{*}{ Not Significant } \\
\hline & Without Dependents & 3.45 & 0.94 & & & \\
\hline & & Mean & SD & $\mathrm{T}(94)$ & $\mathrm{P}$ & Interpretation \\
\hline \multirow{2}{*}{ Sex } & Female & 3.52 & 0.98 & -0.30 & 0.35 & Not Significant \\
\hline & & Mean & $\mathrm{Sd}$ & $\mathrm{F}(2,93)$ & $\mathrm{P}$ & Interpretation \\
\hline \multirow{4}{*}{ Monthly Gross Income } & P50,000 \& Above & 4.02 & 0.98 & \multirow{3}{*}{2.10} & \multirow{3}{*}{0.13} & \multirow{3}{*}{ Not Significant } \\
\hline & $\mathrm{P} 25,000-\mathrm{P} 49,000$ & 3.62 & 0.99 & & & \\
\hline & P24,000 \& Below & 3.35 & 0.83 & & & \\
\hline & & Mean & SD & $\mathrm{F}(4,91)$ & $\mathrm{P}$ & Interpretation \\
\hline \multirow{5}{*}{ Tenure } & 1-5 Years & 3.38 & 0.89 & \multirow{4}{*}{0.99} & \multirow{4}{*}{0.42} & \multirow{4}{*}{ Not Significant } \\
\hline & 6-10 Years & 3.30 & 0.92 & & & \\
\hline & 21-30Years & 3.71 & 1.07 & & & \\
\hline & 31 Years \& Above & 2.70 & 0.52 & & & \\
\hline & & Mean & SD & $\mathrm{T}(94)$ & $\mathrm{P}$ & Interpretation \\
\hline \multirow{2}{*}{ Job Position } & Teaching & 3.57 & 0.95 & \multirow{2}{*}{0.96} & \multirow{2}{*}{0.52} & \multirow{2}{*}{ Not Significant } \\
\hline & Non-Teaching Staff & 3.37 & 0.92 & & & \\
\hline
\end{tabular}

Given the mean scores in the table, this result means that those whose age falls from 34 to 47 years old significantly have a better financial behavior than the rest of the age groups. This group consists of employees who pay their bills/loans on time, own a bank account which they update every month, pay in cash instead of using credit cards, consider their financial situation before purchasing anything, and paying particular attention to items that they buy. The same table also reveals that there is no significant difference in the employees' level of financial behavior when grouped according to family status, sex, monthly income, job position, and tenure.

Moreover, Table 13 reveals that there is no significant difference in the employees' level of financial stress when grouped according to age, family status, tenure, and job position. However, in terms of monthly income, the results show that a significant difference exists and that those who earn between P 24, 000 and below significantly experience more financial stress compared to those who are earning more. This result implies that employees who belong to the lowest salary scale experience more financial stress. This is the group of employees who have trouble paying their bills 
on time, may not afford the medical cost in case of sickness, and have trouble making ends meet for their family's needs.

Table 13. Difference in the employees' level of financial stress.

\begin{tabular}{|c|c|c|c|c|c|c|}
\hline Variables & & Mean & SD & $F(2,93)$ & $\mathbf{p}$ & Interpretation \\
\hline \multirow{4}{*}{ Age } & $20-33$ & 2.19 & 0.76 & \multirow{3}{*}{3.01} & \multirow{3}{*}{0.54} & \multirow{3}{*}{ Not Significant } \\
\hline & $34-47$ & 2.69 & 0.95 & & & \\
\hline & $48 \&$ Above & 2.31 & 0.83 & & & \\
\hline & & Mean & SD & $\mathrm{T}(94)$ & $\mathrm{p}$ & Interpretation \\
\hline \multirow{3}{*}{ Family Status } & With Dependents & 2.44 & 0.84 & \multirow{2}{*}{0.33} & \multirow{2}{*}{0.46} & \multirow{2}{*}{ Not Significant } \\
\hline & Without Dependents & 2.38 & 0.97 & & & \\
\hline & & Mean & SD & $\mathrm{T}(94)$ & $\mathrm{p}$ & Interpretation \\
\hline \multirow{3}{*}{ Sex } & Male & 2.56 & 0.93 & \multirow{2}{*}{2.07} & \multirow{2}{*}{0.33} & \multirow{2}{*}{ Not Significant } \\
\hline & Female & 2.18 & 0.74 & & & \\
\hline & & Mean & SD & $F(2,93)$ & $\mathrm{p}$ & Interpretation \\
\hline \multirow{4}{*}{ Monthly Gross Income } & P50,000 \& Above & 1.38 & 0.33 & \multirow{3}{*}{5.33} & \multirow{3}{*}{$0.01 *$} & \multirow{3}{*}{ Significant } \\
\hline & $\mathrm{P} 25,000-\mathrm{P} 49,000$ & 2.41 & 0.97 & & & \\
\hline & P24,000 \& Below & 2.55 & 0.78 & & & \\
\hline & & Mean & SD & $\mathrm{F}(4,91)$ & $\mathrm{p}$ & Interpretation \\
\hline \multirow{6}{*}{ Tenure } & 1-5 Years & 2.50 & 0.77 & \multirow{5}{*}{0.39} & \multirow{5}{*}{0.81} & \multirow{5}{*}{ Not Significant } \\
\hline & 6-10 Years & 2.26 & 0.75 & & & \\
\hline & 11-20Years & 2.54 & 1.03 & & & \\
\hline & 21-30Years & 2.42 & 1.17 & & & \\
\hline & 31 Years \& Above & 2.83 & 0.76 & & & \\
\hline & & Mean & SD & $\mathrm{T}(94)$ & $\mathrm{p}$ & Interpretation \\
\hline \multirow{2}{*}{ Job Position } & Teaching & 2.60 & 0.88 & \multirow{2}{*}{1.25} & \multirow{2}{*}{0.90} & \multirow{2}{*}{ Not Significant } \\
\hline & Non-Teaching Staff & 2.36 & 0.85 & & & \\
\hline
\end{tabular}

\subsection{Relationship between the Employees' Financial Literacy and Behavior, Financial Literary and Stress, and Financial Behavior and Stress}

Table 14 shows that financial literacy and financial behavior are substantially related. This means that the employees' level of financial literacy significantly affects their financial behavior. This result implies that for them to have a better way of managing their financial resources, it will help if they can be properly educated about the things they need to know. This finding supports that of Lusardi and Mitchell [15] and Hilgerth et al. [8] who had earlier established a relationship between financial literacy and financial behavior. In their study, they found out that a person's financial behavior is affected by his financial literacy.

Meanwhile, the table also reveals that there is no significant relationship between the employees' financial literacy and financial stress and between their financial behavior and financial stress.

Table 14. Relationship among factors between the employees' financial literacy and financial behavior, financial literacy and financial stress, and financial behavior and financial stress.

\begin{tabular}{lllll}
\hline Factors & $\mathbf{r}$ & $\mathbf{r}^{2}$ & $\mathbf{p}$ & Interpretation \\
\hline Financial Literacy & $0.692^{*}$ & 0.479 & 0.000 & Substantial Relationship \\
Financial Behavior & 0.022 & 0.0005 & 0.83 & No Relationship \\
$\begin{array}{l}\text { Financial Literacy } \\
\text { Financial Stress }\end{array}$ & 0.039 & 0.0015 & 0.70 & No Relationship \\
$\begin{array}{l}\text { Financial Behavior } \\
\text { Financial Stress }\end{array}$ & & & \\
\hline
\end{tabular}

*Significant at 0.05 alpha level of significance.

\subsection{Predictors of Financial Wellness}

Furthermore, a multiple regression was run to find out which among the factors (financial literacy, financial behavior, and financial stress) could predict financial wellness. This result shows that financial literacy and financial stress are, statistically, determinants of financial wellness. So, the general form of the equation to predict financial wellness is: predicted financial wellness $=0.975+$ (0.685 x financial literacy) $-(0.144 \times$ Financial Stress $)$. This means that $68.5 \%$ of the variance of financial wellness can be attributed to financial literacy provided that the level of financial stress is below zero.

\section{Discussion}

This investigation has provided evidence that the employees' demographic profile, particularly their age, family status, sex, monthly income, job position, and tenure, may have some bearing on their financial wellness. These findings are corroborated by the study of Joo (1998) who had found certain demographic characteristics such as his marital status, income, education, age and the number of dependents in the household, as well as his financial knowledge as influential to an individual's financial wellness [13].

The fair level of financial wellness and the moderate level of 
financial literacy discovered among the employees indicate the need to include financial education as an administrative initiative to improve the employees' ability to manage their financial resources. Considering that what the employees earn is just enough for their basic needs, it is highly relevant to also educate them on how to cope with and prepare for unexpected changes and unfavorable financial situations such as job loss, health problems, or emergency cases.

One's monthly income or salary has been found crucial in attaining financial wellness. Hence, hierarchical advancement which subsequently leads to salary promotion should be made part of every employee's career plans. Inasmuch as age could significantly spell a difference in the employees' financial wellness, a sound financial management must be emphasized across the employees' cycle in preparation to their retirement where a fall in the income begins and the period of dissaving is high.

The study has also revealed a domino relationship between an individual's financial literacy, financial behavior, financial stress, and financial wellness. Based on this evidence, it can be said that if one's financial literacy is improved, this literacy can direct his behavior on managing his financial resources, thereby reducing his level of financial stress, and subsequently improving his financial wellness. This relationship is supported by previous studies that had established financial literacy as an influential factor in improving a person's financial behavior, and financial stress as an adverse effect of an individual's lack of financial knowledge [8], [15].

Finally, with financial literacy being identified as the best factor that could determine financial wellness, it is significant that it should be provided to the employees to provide them a better direction towards better financial wellness, and a security blanket in case of financial crisis and in preparation for their retirement.

\section{Conclusion}

In conclusion, financial wellness is not just a mental state as there are factors that influence it. It is something that needs to be learned and be made part of a person's way of life. Financial literacy plays a significant role in developing the right financial behavior. Thismeans that a person may have more success in managing his/her financial resources if he/she is financially literate, to begin with. The ability to manage one's financial resources after he/she has acquired the knowledge of doing it could mean less financial stress and a better financial wellness.

\section{Recommendations}

For the employees, a clear budget plan is encouraged to discern between needs and wants. Each employee needs to reexamine his or her budget performance vis-à-vis his/her actual net pay. If possible, loans and use of credit cards must be minimized. There is also a need for them to set aside a budget for emergency purposes. The administration, through the Human Resource Office, could identify a suitable seminar-workshop or a quick course on financial management to further educate the employees on how to manage their financial resources. A financial wellness program can also be designed to better prepare the employees in case of emergencies or illness and help them in making smart decisions when it comes to managing their finances. This financial wellness program may include basic financial behaviors that benefit both employee and employer such as budgeting and money management skills, debt reduction, credit management, and financial goal setting such as increasing savings. Future researchers could use this paper as a point of reference by replicating this study in the context of their workplace. It can also be a basis for considering other variables that could affect the financial wellness of various groups of people outside the workplace.

\section{References}

[1] Pricewaterhouse Coopers LLP (2015). Employee Financial Wellness Survey. Retrieved from http://www.pwc.com/us/en/private-companyservices/publications/assets/pwc-employee-financial-wellnesssurvey-2015.pdf.

[2] Rubinstein, M. (2017). Top Causes of Financial Stress. Retrieved from https://www.pinpoint.money/blog/2017/october/11/top-causesof-financial-stress/.

[3] Employee Financial Wellness and Its Impact on Workplace Productivity and Cost of Benefits. Retrieved from https://www.informationexperts.com/wpcontent/uploads/2017/03/EmployeeFinancialWellness_ Whitepaper-1.pdf.

[4] Lusardi, A. (2006). Financial Literacy and Financial Education: Review and Policy Implications (May 2006). NFI Policy Brief No. 2006-PB-11. Retrieved from http://papers.ssrn.com/sol3/papers.cfm?abstract_id=92 3437.

[5] The Manila Times (December 2, 2015). Retrieved from http://www.manilatimes.net/only-25-of-filipinos financiallyliterate-sp/232428/.

[6] Braunstein S, Welch C (2002). Financial literacy: An overview of practice, research, and policy. Fed. Res. Bull., 88: 445.

[7] Perry VG (2008). Is ignorance bliss? Consumer accuracy in judgments about credit ratings. J. Consum. Aff., 42 (2): 189205. Perry VG (2008). Is ignorance bliss? Consumer accuracy in judgments about credit ratings. J. Consum. Aff., 42 (2): 189-205.

[8] Hilgert MA, Hogarth JM, Beverly SG (2003). Household financial management: The connection between knowledge and behavior. Fed. Res. Bull., pp. 309-322.

[9] Garman E, Porter N, McMillion J (1989). Financial counseling by a corporation with a large number of employees. Proceedings of the 18th Annual Southeastern Regional Family Economics/Home Management Conference, pp. 76-84. 
[10] Weaver, P., \& Rollins, G. (2008). Easing the burden of employees' debt. HR Magazine, 53 (7), 61-64.

[11] Delafrooz, N. \& Paim, L. (2011). Determinants of financial wellness among Malaysia Workers, African Journal of Business Management Vol. 5 (24), pp. 10092-10100, Retrieved from http://www.academicjournals.org/AJBM, DOI: 10.5897/AJBM10.1267.

[12] Deaton, A. (2005). Franco Modigliani and the Life Cycle Theory of Consumption. Research Program in Development Studies and Center for Health and Wellbeing Princeton University. Retrieved from https://www.princeton.edu/ deaton/downloads/romelecture.pd f.

[13] Joo, S. (1998). Personal Financial Wellness and Worker Job Productivity. Dissertation submitted to the Faculty of the Virginia Polytechnic Institute and State University. Retrieved from https://theses.lib.vt.edu/theses/available/etd-4198155242/unrestricted/FRONTM_1.PDF.

[14] Robb, C. A., \& Woodyard, A. (2011). Financial knowledge and best practice behavior. Journal of Financial Counseling and Planning, 22 (1), 60-70.
[15] Lusardi A, Mitchell OS (2007). Baby boomer retirement security: The roles of planning, financial literacy, and housing wealth. J. Monet. Econ., 54 (1): 205-224.

[16] The Impact of Financial Stress on Workforce Productivity (February 27, 2014). Retrieved from http://pensionconsultants.com/the-impact-of-financial-stress-on-workforceproductivity/.

[17] Ariola, M. (2006). Principles and Methods of Research, First Edition. Manila: Rex Bookstore.

[18] Oppong-Boakye, P. K., and Kansanba, R. (2013). An Assessment of Financial Literacy Levels among Undergraduate Business Students in Ghana. Research Journal of Finance and Accounting, Vol. 4, No. 8. Retrieved from http://www.iiste.org/Journals/index.php/RJFA/arti cle/viewFile/6692/7102.

[19] Hillman, K. (2015). “What Is Financial Stress?” Journal of Stress Management. Retrieved from http://www.stresstips.com/what-is- financial-stress. 